\title{
Motor performance in Kaingang indigenous children
}

\author{
Itamar Adriano Tagliari ${ }^{1}$, Antonio de Azevedo Barros Filho², Maria Beatriz Rocha Ferreira ${ }^{3}$
}

DOI: http://dx.doi.org/10.7322/jhgd.113713

\begin{abstract}
Introduction: Studies on indigenous children show low height for age, however there is a lack of literature on motor performance in these populations. Motor performance tests are important indicators in identifying factors of physical fitness related to health.

Objective: To compare the motor performance in Kaingang indigenous children.

Methods: The study was descriptive and cross-sectional with 78 Kaingang schoolchildren aged between 8 and 9 years from the indigenous area of Rio das Cobras, in Paraná, Brazil. The children were classified into two groups, Group A below (GA) and Group B (GB) above the -2 z-scores for the reference stature for age from the Centers for Disease Control and Prevention/National Center for Health Statistics. The data were collected using anthropometric measurements of their stature and motor performance tests for sitting and reaching (flexibility), jumping distance (muscle power), sitting and lying down (strength and muscular resistance) and coming and going (agility). Analysis of covariance ( $\mathrm{p}<$ 0.05 ) was used to compare the stature between the groups as well as their motor performance, controlled by age, and separated per sex.

Results: Among the 78 schoolchildren evaluated, $45.5 \%$ of boys and $55.5 \%$ of girls were below the $-2 z-$ scores for stature at their age, classified in GA, and $54.5 \%$ of boys and $44.5 \%$ of girls were above the -2 z-scores for stature at their age, classified in GB. There was a significant difference in stature between the groups, in both sexes. There was a significant difference in the motor performance tests between children classified as having a short stature and those not characterized as such, in both sexes.
\end{abstract}

Conclusion: Short stature did not influence motor performance in the children studied.

Keywords: engine performance, physical growth, short stature.

\section{INTRODUCTION}

The World Health Organization (WHO) ${ }^{1}$ recommends anthropometric measurements as a means to study the physical growth of individuals and the community. Short stature for age is defined as the condition in which an individual is two standard deviations below the average height of children of the same age and sex. The $\mathrm{WHO}^{1}$ suggests that anthropometric data of children should be compared to a reference population. Data from the Centers for Disease Control and Prevention (CDC)/National Center for Health Statistics (NCHS) are widely used in scientific studies ${ }^{2}$.
Most research with indigenous people focuses on growth and nutritional problems, such as low height ${ }^{3-6}$. The data reveal frequencies of short stature exceeding $40 \%$ in indigenous children between 0 and 9/10 years of age, as reported in studies conducted among indigenous people in Brazil published since $1990^{7}$.

The health situation of many indigenous people in Brazil is due largely to a combination of a lack of areas for production, a rapid increase in the population and drastic socio-economic and cultural changes, with the loss of original economic alternatives and the introduction of new alimentary standards ${ }^{7}$, in addition to infectious and contagious alimentary diseases in children ${ }^{8}$, characterized

1 Doutor em Saúde da Criança e do Adolescente pela Universidade Estadual de Campinas; Professor Associado do Departamento de Educação Física da Universidade Estadual de Ponta Grossa.

2 Doutor em Pediatria pela Universidade de São Paulo; Professor Titular do Departamento de Pediatria da Universidade Estadual de Campinas.

3 Doutora em Antropologia pela Universidade do Texas; Professora Visitante Sênior da Faculdade de Educação da Universidade Federal da Grande Dourados

Corresponding author: E-mail: itagliari@ig.com.br

Suggested citation: Tagliari IA, Barros Filho AA, Rocha Ferreira MB. Motor performance in kaingang indigenous children. J Hum Growth Dev. 26(1): 48-53. Doi: http://dx.doi.org/10.7322/jhgd.113713

Manuscript submitted: Feb 21 2016, accepted for publication Feb 262016. 
as important elements in understanding the health-disease process of indigenous people. These factors, coupled with inadequate feeding, are singled out as causes of proteinenergy malnutrition, which is reflected in the growth, muscle mass and work capacity reduction and low levels of performance in speed tests, long-distance races and strength $^{9,10}$.

Daily physical activity and heredity are still associated with many factors of health-related physical fitness, including flexibility, agility, strength, endurance and muscular power ${ }^{11}$. Strength and muscular endurance are highlighted as important components of physical fitness for children and adolescents, as well as the emphasis on activities related to children's motor skills ${ }^{12}$.

Studies with the people of Kaingang verified that there were children with short stature for their age ${ }^{13}$ however, issues involving physical growth related to motor characteristics weren't discussed. Therefore, the objective of this study is to compare the motor performance in indigenous Kaingang children.

\section{METHODS}

It is a descriptive and cross-sectional study, carried out on indigenous area of Rio das Cobras, in Paraná, Brazil, demarcated by the National Indigenous Foundation (FUNAI $)^{14}$, located in the municipality of Nova Laranjeiras, Paraná, Brazil, where the Kaingang people live.

The Kaingang people, who traditionally lived by hunting, gathering and agriculture, today survive off plantations managed by FUNAI, off family plantations, off the sale of handicrafts and off the provision of services to rural producers. With the decrease of their land, they were confined in spaces that don't meet the families' material needs ${ }^{15}$.

For the realization of the study, all of the 86 children between 8 and 9 years of age of the Kaingang creed, enrolled in schools of the indigenous land of Rio das Cobras, located in the municipality of Nova Laranjeiras, Paraná, Brazil, were invited to participate. In total, 78 schoolchildren were evaluated - 33 boys and 45 girls - whose parents authorized their participation and attendance in data collection. It was chosen to study children between 8 and 9 years of age due to the fact that they were at a stage prior to sexual maturation and they were physically able to realize the motor performance tests proposed. In addition, they were children who had managed to overcome the difficulties of the hostile environment and served as an indicator for understanding the potential problems caused by younger children.

The 78 children were classified, according to the height index age (E/I) of the reference Centers for Disease Control and Prevention (CDC)/National Center for Health Statistics (NCHS) ${ }^{2}$, in two groups: Group A (GA), below -2 z-score of height for age, and Group B (GB), above -2 z-score of stature for age. Boys and girls were analysed separately. The GA was composed of 15 boys ( $>-3.55$ and $<-2$ z-score) and 25 girls ( $>-3.89$ and $<-2$ score $\mathrm{z}$ ), and the GB was composed of 18 children ( $>-2$ and $<-0.24 \mathrm{z}$ score) and 20 girls ( $>-2$ and $<-0.73 \mathrm{z}$ score).
The data were collected by means of motor performance testing and anthropometric measurement. The performance tests were used as indicators of flexibility, muscular power, agility, strength and muscular endurance: i) sit and reach (Wells), centimetres (flexibility) ${ }^{16}$ ii) long jump, centimetres (muscular power) ${ }^{17}$ iii) sit and lie down (abdominal), repeat in 1 minute (strength and muscular endurance) ${ }^{16}$ and iv) come and go (shuttle run), seconds $(\text { agility })^{18}$.

For the anthropometric assessment, the height was measured using the stadiometer from the brand Seca, mounted on the wall. The measures followed the recommendations published in a reference manual for anthropometric measures ${ }^{19}$.

All measures of performance and of anthropometry were taken and recorded by a group of previously trained evaluators.

The percentage was used to analyse the stature of children in the GA and GB. Analysis of covariance (ANCOVA) (SPSS) was used to compare the results of the measures of stature, as well as the results of each of the motor performance tests depending on the factor children characterized with short stature (GA) and other children (GB), controlling for age, with separation by gender. Bonferroni adjustment was used for post hoc comparisons. The significance level adopted for statistical tests was $5 \%$.

The project for the completion of this survey has been approved by the National Committee for Ethics in Research (CONEP), under case number 25000.096846/ 2004-08.

\section{RESULTS}

A total of 78 schoolchildren from the Kaingang creed participated; they were between 8 and 9 years of age, of both sexes - 33 boys and 45 girls - and indigenous residents of Rio das Cobras, municipality of Nova Laranjeiras, State of Paraná, Brazil. The schoolchildren were classified according to the height to age (H/A) index CDC/ reference NCHS2, in two groups, separated by sex. Group A (GA) had 15 boys and 25 girls with below -2 z-score of stature for age, and Group B (GB) featured 18 boys and 20 girls with above $-2 \mathrm{z}$-score of stature for age.

The results indicate that $45.5 \%$ of the boys and $55.5 \%$ of the girls were below -2 z-score of stature for age, classified in GA, and $54.5 \%$ of the boys and $44.5 \%$ of the girls were above $-2 \mathrm{z}$-score of stature for age, classified in GB.

In Table 1 the means and standard deviations of anthropometric measurements and motor performance tests are shown. The measures of stature among the two groups were compared by means of ANCOVA, controlled by age, and separated by gender. The GA showed significantly less stature than the GB, in both genders, as shown in Table 2 .

The results of the tests of motor performance, such as the sit and reach (flexibility), long jump (muscle power), sit and lie down (strength and muscular endurance) and the come and go (agility), between the GA and GB are compared through the ANCOVA mean, controlled by DISCUSSION 
Table 1: Means values and standard deviations (Sd) for anthropometric measurements and performance tests by sex and groups [A and $B]$

\begin{tabular}{|c|c|c|c|c|c|c|c|c|}
\hline & \multicolumn{4}{|c|}{ Male } & \multicolumn{4}{|c|}{ Female } \\
\hline & \multicolumn{2}{|c|}{$\begin{array}{c}\text { Group A } \\
n=15\end{array}$} & \multicolumn{2}{|c|}{$\begin{array}{l}\text { Group B } \\
n=18\end{array}$} & \multicolumn{2}{|c|}{$\begin{array}{c}\text { Group A } \\
n=25\end{array}$} & \multicolumn{2}{|c|}{$\begin{array}{c}\text { Group B } \\
n=20\end{array}$} \\
\hline & Median & $\mathrm{Sd}$ & Median & $\mathrm{Sd}$ & Median & $\mathrm{Sd}$ & Median & $\mathrm{Sd}$ \\
\hline Age $\quad 9,0$ & 0,5 & 9,0 & 0,6 & 8,8 & 0,6 & 8,9 & 0,6 & \\
\hline Height, cm. & 117,0 & 3,6 & 128,4 & 4,2 & 115,9 & 3,7 & 123,3 & 3,5 \\
\hline $\begin{array}{l}\text { Sit ans lie down, n/1 } \\
\text { min. }\end{array}$ & 18,3 & 6,4 & 20,2 & $\begin{array}{c}10 \\
9\end{array}$ & 16,8 & 6,8 & 18,3 & 8,7 \\
\hline Sit and reach, cm. & 34,0 & 2,5 & 34,0 & 2,2 & 35,6 & 2,5 & 34,4 & 2,7 \\
\hline Come and Go, sec. & 13,2 & 1,2 & 12,9 & 0,9 & 14,0 & 0,9 & 13,6 & 0,9 \\
\hline Horizontal jump, cm. & 115,1 & 18,1 & 123,8 & 17,5 & 107,0 & 13,3 & 113,0 & 14,8 \\
\hline
\end{tabular}

Group 1: (bellow -2 z score of height for the reference age CDC/NCHS 2000)

Group 2: (above $-2 \mathrm{z}$ score of height for the reference age CDC/NCHS 2000)

age, with separation by gender. The results indicate that in none of the motor performance tests are the differences between the averages significant, among children charac- terized with low stature compared with those not featured with short stature, in both genders, which can be seen in Table 2.

Table 2: Means, standard errors (Se) and ANCOVA of height and performance tests by sex and groups [A and B] after age was controlled

\begin{tabular}{|c|c|c|c|c|c|c|c|c|c|c|}
\hline & \multicolumn{4}{|c|}{ Male } & \multicolumn{6}{|c|}{ Female } \\
\hline & \multicolumn{2}{|c|}{$\begin{array}{c}\text { Group A } \\
n=15\end{array}$} & \multicolumn{2}{|c|}{$\begin{array}{c}\text { Group B } \\
n=18\end{array}$} & \multirow[t]{2}{*}{$\mathrm{p}$} & \multicolumn{2}{|c|}{$\begin{array}{c}\text { Group A } \\
\mathrm{n}=25\end{array}$} & \multicolumn{2}{|c|}{$\begin{array}{c}\text { Group B } \\
n=20\end{array}$} & \multirow[t]{2}{*}{$\mathrm{p}$} \\
\hline & Median & $\mathrm{Sd}$ & Median & $\mathrm{Sd}$ & & Median & Sd & Median & $\mathrm{Sd}$ & \\
\hline Height, $\mathrm{cm}$. & 117,2 & 0,7 & 124,6 & 0,6 & ,000 & 116,1 & 0,5 & 123,1 & 0,5 &, 000 \\
\hline $\begin{array}{l}\text { Sit and lie down, n/1 } \\
\text { min. }\end{array}$ & & & & & & & & & & \\
\hline min. & $\begin{array}{l}18,4 \\
340\end{array}$ & 2,4 & 20,1 & 2,1 & ,579 & 16,6 & 1,5 & 18,5 & 1,6 &, 518 \\
\hline Sit and reach, $\mathrm{cm}$. & 34,0 & 0,6 & 34,0 & 0,5 & ,816 & 35,6 & 0,4 & 34,3 & 0,5 & 051 \\
\hline Come and go, sec. & 13,2 & 0,2 & 12,9 & 0,2 &, 30 & 14,0 & 0,1 & 13,6 & 0,1 & , 145 \\
\hline Horizontal jump, $\mathrm{cm}$. & 115,2 & 4,6 & 123,8 & 4,2 & 1,275 & 106,8 & 2,7 & 113,3 & 3,1 & 137 \\
\hline
\end{tabular}

Group 1: (bellow $-2 \mathrm{z}$ score of height for the reference age CDC/NCHS 2000)

Group 2: (above $-2 \mathrm{z}$ score of height for the reference age CDC/NCHS 2000)

The Kaingang creed authorized the participation of children in the survey, after making teacher aware of the work to be performed. The children had to have an initial phase of contact and clarification of the tests. All were accepting during the fieldwork, participating in the anthropometric measurements, and have had no difficulties in carrying out the tests, except for agility. This test was a novelty and so they could take over the standard machine needed first to practise walking in a smaller space and then carry out the test in accordance with the specifications.

The results of this study indicate that the majority of children are below -2 z-score of stature for age. These results corroborate other indigenous population studies that demonstrate, in general, lower than average stature of the national population ${ }^{20-23}$. The data reveal frequencies of short stature exceeding $40 \%$ in indigenous children between 0 and 9/10 years of age, as reported in some studies conducted among indigenous people in Brazil published since $1990^{7}$.

The literature indicates the following causes for short stature: 1 . Short stature inherited from the family; 2. Short stature due to diseases linked to intrinsic factors, individual growth or biological; 3. Short stature due to diseases related to extrinsic factors, population or environmental growth ${ }^{24}$.
Short stature in the indigenous population may be related to genetic, adaptive processes of Asian ${ }^{25}$ ancestors and a hostile environment, such as poor diet and health issues. Specifically in the case of the Kaingang people, there was a decrease of their land, and they were confined in spaces that didn't meet the material needs of their families ${ }^{15}$.

Other population studies also point out the influence of environmental factors on physical growth, showing that short stature is associated with the economic condition of the family, birth weight and maternal education $^{26}$. In addition, inadequate nutrition contributes to protein-energy malnutrition, which is reflected in the growth and reduction in levels of performance in motor tests ${ }^{9,10}$.

Table 2 presents the results related to differences in the motor performance tests of indigenous children, classified in two groups, with Group A (GA) ranked below and Group B (GB) up to -2 z-score height to age, allowing us to verify the differences in motor performance in children's of low socio-economic level, one of them being featured with short stature for age as the CDC/reference $\mathrm{NCHS}^{2}$.

When comparing the results of the tests of motor performance - sit and reach, sit and lie down, come and go and long jump - of the Kaingang indigenous children, in GA and GB, no significant differences were found in 
any of the tests, in both genders. In another school that was verified with a study ${ }^{27}$, groups with normal and reduced flexibility did not show significant differences with respect to time.

When comparing the results of this research with the percentile curve drawn from children in the city of Londrina, Paraná, Brazil ${ }^{28}$, it was verified that in horizontal jump, boys of the GA were between the 10th and 25th percentile, and those of the GB near the 25th percentile, while the girls of the GA were between the 10th and 25th percentile, and those of the GB were close to the 25th percentile. In sit and lie down, the boys of the GA were close to the 5th percentile, and those of the GB close to the 10th percentile, while the girls of the GA were close to the 5th percentile, and those of the GB close to the 10th percentile. In the sit and reach test, both groups and genders were above the 95th percentile.

Comparing the results of this study in the sit and reach test with those presented nationally ${ }^{29}$, it was found that both male and female groups are above the cut-off points, and are considered to have the desired levels of health-related physical fitness. In the sit and lie down test, involving the physical valances abdominal strength and endurance, compared with the same reference, the values found in this study are below the cut-off points. The results below the cut-off point show the increased probability of risk indicators of the presence of postural deviations and complaints of back pain, as the Sport Project Brasil ${ }^{29}$.

It is concluded that the stunting of indigenous people as evidenced in different research may reflect processes of adaptation to the environment. sShort stature did not influence the results of the tests of motor performance of the children studied.

The children investigated present flexibility and the desired levels of health-related physical fitness. However, the development of their strength and abdominal strength requires more attention. The results of the test indicate that abdominal strength and endurance are risk factors for the health of indigenous children in both sexes.

There is a need for programmed physical activities that can contribute to the improvement of motor performance test results in abdominal strength and endurance for those children evaluated, while always respecting the socio-cultural characteristics of indigenous people.

\section{REFERENCES}

1. World Health Organization (WHO). Physical Status: The Use and Interpretation of Anthropometry. Geneva: World Health Organization; 1995; p. 198-214.

2. Centers for Disease Control and Prevention (CDC). National Center for Health Statistics (NCHS). [cited 2015 Sep 15] Available from: http://www.cdc.gov/nchs.

3. Coimbra Jr CE, Santos RV, Welch JR, Cardoso AM, Souza MC, Garnelo L, et al . The First National Survey of Indigenous People's Health and Nutrition in Brazil: rationale, methodology, and overview of results. BMC Public Health. 2013;13: 52. DOI: http://dx.doi.org/10.1186/1471-2458-13-52

4. Leite MS, Santos RV, Coimbra JR CEA. Sazonalidade e estado nutricional de populações indígenas: o caso Wari', Rondônia, Brasil. Cad Saúde Pública. 2007;23(11): 2631-42. DOI. http://dx.doi.org/10.1590/ S0102-311X2007001100011

5. Orellana JDY, Coimbra Jr CEA, Lourenço AEP, Santos RV. Estado nutricional e anemia em crianças Suruí, Amazônia, Brasil. J Pediatr (Rio J). 2006;82(5): 383-8. DOI. http://dx.doi.org/10.1590/S002175572006000600013

6. Escobar AL, Santos RV, Coimbra Jr CEA. Avaliação nutricional de crianças indígenas Pakaanóva (Wari'), Rondônia, Brasil. Rev Bras Saúde Mater Infant. 2003;3(4): 457-61. DOI. http://dx.doi.org/10.1590/S151938292003000400010

7. Santos RV, Coimbra Jr CEA. Cenários e tendências da saúde e da epidemiologia dos povos indígenas no Brasil. In: Coimbra Jr CEA, Santos RV, Escobar AL. Epidemiologia e saúde dos povos indígenas no Brasil. Rio de Janeiro: Fiocruz; 2003; p. 13-47.

8. Fundação Nacional de Saúde (FUNASA). Manual de Atenção à Saúde da Criança Indígena Brasileira. Brasília: Fundação Nacional de Saúde; 2004; p. 28-31.

9. Spurr GB. Nutritional status and physical work capacity. Am J Phys Anthropol. 1983;26(Suppl. 1): 1-35. DOI: http://dx.doi.org/10.1002/ajpa.1330260503

10. Ferreira MBR, Malina RM, Rocha LL. Anthropometric, functional and psychological characteristics of eight-year old Brazilian children from low socioeconomic status. In: Shepahrd RJ, Parizkova J. (eds). Human Growth, Phys Fitness Nutrition. 1991;31: 109-118. DOI: http://dx.doi.org/10.1159/000419554

11. Bouchard C, Shepard RJ, Stephens T. Physical Activity, Fitness, and Health: International Proceedings and Consensus Statement. Champaign: Human Kinetics Publishers; 1993; p.1-102.

12. Strong W, Malina R, Blimkie CJR, Daniels SR, Dishman RK, Gutin B, et al. Evidence based physical activity for school-age youth. J Pediatr. 2005;146(6): 732-7. DOI: http://dx.doi.org/10.1016/j.jpeds.2005.01.055 
13. Castro TG, Schuch I, Conde WL, Veiga J, Leite MS, Dutra CLC, et al. Estado nutricional dos indígenas Kaingáng matriculados em escolas indígenas do Estado do Rio Grande do Sul, Brasil. Cad Saúde Pública. 2010;26(9): 1766-76. DOI: http://dx.doi.org/10.1590/S0102-311X2010000900010

14. Instituto Brasileiro de Geografia e Estatística (IBGE). Anuário Estatístico do Brasil. Vol. 51. Rio de Janeiro: IBGE; 1991; p. 53-64.

15. Tomassino KE, Fernandes R. Kaingang. Instituto Socioambiental. [cited 2006 Mar 15] Available from: http://www.socioambiental.org/pib/epi/kaingang/hist.shtm

16. American Alliance for Health, Physical Education, Recreation and Dance (AAPHER). Health-related physical fitness test manual. Reston: 1980.

17. American Alliance for Health, Physical Education, Recreation and Dance (AAPHER). Health-related physical fitness test manual. Washington: 1976. p. 31.

18. Matsudo VKR. Testes em ciências do esporte. São Paulo: Gráficos Burti; 1987. p. 73-76.

19. Lohman TG, Roache AF, Martorell R. Anthropometric standartization reference manual. Champaign, Illinois: Human Kinetics Books; 1991; p. 3-8.

20. Santos RV. Crescimento físico e estado nutricional de populações indígenas brasileiras. Cad Saúde Pública. 1993;9(Supl.1):46-57. DOI: http://dx.doi.org/10.1590/S0102-311X1993000500006

21. Fagundes U, Kopelman B, Oliva CAG, Baruzzi RG, Fagundes-Neto U. Avaliação do estado nutricional e da composição corporal das crianças índias do Alto Xingu e da etnia Ikpeng. J Pediatr. (Rio de J). 2004;80(6):483-9. DOI: http://dx.doi.org/10.1590/S0021-75572004000800010

22. Sampei MA, Canó EM, Fagundes U, Lima EES, Rodrigues D, Sigulem DM, et al. Avaliação antropométrica de adolescentes Kamayurá, povo indígena do Alto Xingu, Brasil Central (2000-2001). Cad Saúde Pública. 2007;23(6):1443- 53. DOI: http://dx.doi.org/10.1590/S0102-311X2007000600019

23. Ferreira AA, Welch JR, Santos R, Gugelmin S, Coimbra CEA. Nutritional status and growth of indigenous Xavante children, Central Brazil. Nutrition J. 2012;11:3. DOI: http://dx.doi.org/10.1186/1475-2891-11-3

24. Marcondes E. Fatores ambientais do crescimento da criança. Rev Bras Crescimento Desenvolv Hum. 1991;1(1):10-24.

25. Ribeiro DM, Figueiredo MS, Costa FF, Sonati MF. Haplotypes of the Alpha-Globin Gene Regulatory Element in two Brazilian Native Populations. Am J Phys Anthropol. 2003;121(1):58-62. DOI: http://dx.doi. org/10.1002/ajpa.10193

26. Orlonski S, Dellagrana RA, Rech CR, Araújo EDS. Estado nutricional e fatores associados ao déficit de estatura em crianças atendidas por uma unidade de ensino básico de tempo integral. Rev Bras Crescimento Desenvolv Hum. 2009;19(1):54-62.

27. Graciosa MD, Coelho JJ, Costa LMR, Medeiros DL, Martinello M, Ries LGK. Efeito do sedentarismo, perfil nutricional e sexo na flexibilidade de escolares. J Hum Growth Dev. 2013; 23(2):144-50. DOI: http://dx.doi. org/10.7322/jhgd.61280

28. Guedes DP, Guedes JERP. Crescimento, composição corporal e desempenho motor de crianças e adolescentes. São Paulo: CLR Balieiro; 1997; p. 261-303.

29. Projeto Esporte Brasil (PROESP/BR). Manual de aplicação de medidas e testes, normas e critérios de avaliação. Porto Alegre: 2009.

This article is distributed under the terms of the Creative Commons Attribution 4.0 International License (http://creativecommons.org/licenses/by/4.0/), which permits unrestricted use, distribution, and reproduction in any medium, provided you give appropriate credit to the original author(s) and the source, provide a link to the Creative Commons license, and indicate if changes were made. The Creative Commons Public Domain Dedication waiver (http://creativecommons.org/publicdomain/zero/1.0/) applies to the data made available in this article, unless otherwise stated. 


\section{Resumo}

Introdução: Estudos em crianças indígenas apontam a baixa estatura para idade, entretanto existe escassez na literatura sobre performance motora nestas populações. Testes de performance motora são importantes indicadores para verificar fatores da aptidão física relacionada a saúde.

Objetivo: Comparar a performance motora em crianças indígenas Kaingang.

Método: $O$ estudo caracterizou-se por ser descritivo e transversal e dele participaram 78 escolares entre 8 e 9 anos de idade, da etnia Kaingang da terra indígena Rio das Cobras, Paraná, Brasil. As crianças foram classificadas em dois grupos: Grupo A (GA) abaixo e Grupo B (GB) acima de -2 escore z de estatura para idade da referência Centers for Disease Control and Prevention/National Center for Health Statistics. Os dados foram coletados por meio da medida antropométrica da estatura e dos testes de performance motora: sentar e alcançar (flexibilidade), salto em distância (potência muscular), sentar e deitar (força e resistência muscular) e ir e vir (agilidade). Utilizou-se a analysis of covariance $(p<0,05)$ para comparar a estatura entre os grupos, bem como a performance motora entre os grupos, controlando pela idade, com separação por sexo.

Resultados: Entre os 78 escolares avaliados, $45.5 \%$ dos meninos e $55.5 \%$ das meninas encontram-se abaixo de -2 escore $z$ de estatura para a idade, classificados no GA, e $54.5 \%$ dos meninos e $44.5 \%$ das meninas acima de -2 escore $z$ de estatura para a idade, classificados no GB, havendo diferença significativa em estatura entre os grupos, em ambos os sexos. Não houve diferença significativa nos testes de performance motora entre as crianças com baixa estatura e aquelas não caracterizadas com baixa estatura, em ambos os sexos.

Conclusão: A baixa estatura não influenciou a performance motora das crianças estudadas.

Palavras-chave: desempenho motor, crescimento físico, baixa estatura. 